\title{
Nitrogen preference across generations under changing ammonium nitrate ratios
}

Stefani Daryanto ${ }^{1,2}$, Lixin Wang ${ }^{1, *}$, William P. Gilhooly III ${ }^{1}$, Pierre-André Jacinthe ${ }^{1}$

${ }^{1}$ Earth Sciences, Indiana University Purdue University Indianapolis, Indianapolis, IN 46202, USA

${ }^{2}$ State Key Laboratory of Earth Surface Processes and Resource Ecology, Faculty of Geographical Science, Beijing Normal University, Beijing 100875, China

Running title: Nitrogen preference across generations

*Corresponding Author

1xwang@iupui.edu

Dept. Earth Sciences

Indiana University Purdue University Indianapolis

Indianapolis, IN 46202, USA

This is the author's manuscript of the article published in final edited form as:

Daryanto, S., Wang, L., Gilhooly, W. P., \& Jacinthe, P.-A. (2018). Nitrogen preference across generations under changing ammonium nitrate ratios. Journal of Plant Ecology. https://doi.org/10.1093/jpe/rty014 


\section{Abstract}

18Aims: Nitrogen $(\mathrm{N})$ in natural environments is typically supplied by a mixture of ammonia 19 $\left(\mathrm{NH}_{4}{ }^{+}\right)$and nitrate $\left(\mathrm{NO}_{3}^{-}\right)$. However, factors that underlie either $\mathrm{NH}_{4}^{+}$or $\mathrm{NO}_{3}^{-}$preference, 20and how such preference will change across generations remain unclear. We conducted a 21series of experiments to answer whether: (i) $\mathrm{NH}_{4}{ }^{+}: \mathrm{NO}_{3}{ }^{-}$ratio is the driving factor for plant $22 \mathrm{~N}$ preference, and (ii) this preference is consistent across generations.

23Methods: We conducted both: (i) field observations (as a proxy for parent or P generation) 24and (ii) greenhouse experiments (the first generation or F1 and the second generation or 25F2) using corn and soybean grown under different $\mathrm{NH}_{4}{ }^{+}: \mathrm{NO}_{3}{ }^{-}$ratios.

26Important findings: Both corn and soybean had the physiological plasticity to prefer either $27 \mathrm{NH}_{4}{ }^{+}$or $\mathrm{NO}_{3}{ }^{-}$depending on $\mathrm{NH}_{4}{ }^{+}: \mathrm{NO}_{3}{ }^{-}$ratios, and this plasticity was consistent across 28generations. Corn, however, showed a stronger preference towards $\mathrm{NO}_{3}{ }^{-}$while soybean 29showed a stronger preference towards $\mathrm{NH}_{4}{ }^{+}$. While both plants would try to make use of 30the most available form of $\mathrm{N}$ in their growing medium, plant species, physiological 31characteristics (e.g., maturity) and plant nutrient status also determined the extent of $\mathrm{N}$ 32 uptake. From the evolutionary and productivity perspective, this plasticity is beneficial, 33allowing plants to effectively acquire available $\mathrm{N}$ particularly in a changing climate.

\section{4}

35Keywords: climate change, filial, isotope, parent, plasticity

\section{6}

37

38 


\section{Introduction}

40Plants require a considerable amount of available nitrogen $(\mathrm{N})$ to support their growth and 41productivity. Since $\mathrm{N}$ is consumed by plants in greater quantity than other macronutrients, 42it most often limits plant growth (Crawford et al., 1998; Wang et al., 2010). Nitrate $\left(\mathrm{NO}_{3}{ }^{-}\right)$ 43and ammonium $\left(\mathrm{NH}_{4}{ }^{+}\right)$commonly serve as the primary sources of $\mathrm{N}$ for plant growth 44(Craine et al., 2015), and both ions can be actively absorbed into root cells, even at low 45external concentrations (Glass et al., 2002). In general, most plants require a mixture of $46 \mathrm{NH}_{4}{ }^{+}$and $\mathrm{NO}_{3}{ }^{-}$rather than a single form of $\mathrm{N}$ (George, 2014), especially considering that 47excessive concentrations of $\mathrm{NH}_{4}^{+}$can be toxic to most plant species.

48 Numerous studies have been conducted to determine plant $\mathrm{N}$ preference $\left(\mathrm{NH}_{4}{ }^{+}\right.$or $49 \mathrm{NO}_{3}{ }^{-}$) under various growing environments and with different plant species (Criddle et al., 501988; Hageman, 1984; Schortemeyer et al., 1996; Smith et al., 1990). Although $\mathrm{NO}_{3}{ }^{-}$

51uptake requires more energy than $\mathrm{NH}_{4}{ }^{+}$because plants need to first absorb $\mathrm{NO}_{3}{ }^{-}$against a 52steep electrochemical gradient before reducing it to $\mathrm{NH}_{4}^{+}$(Britto et al., 2013), most plants, 53particularly agricultural crop species generally prefer $\mathrm{NO}_{3}{ }^{-}$to $\mathrm{NH}_{4}^{+}$. In these plants, $\mathrm{NH}_{4}^{+}$ 54toxicity is usually observed when it serves as the sole source of $\mathrm{N}$ or when it is present in 55excessive quantity (external $\mathrm{NH}_{4}{ }^{+}$concentration $>0.1$ to $0.5 \mathrm{mmol} / \mathrm{L}$ ) (Britto et al., 2002). 56Ammonium toxicity is generally manifested in a reduction of growth, but the threshold at 57which the symptoms become visible differs widely among plant species (Britto and 58Kronzucker, 2002). Agricultural plants that are most sensitive to $\mathrm{NH}_{4}{ }^{+}$toxicity include 59potato (Solanum tuberosum L.), barley (Hordeum vulgare), sugar beet (Beta vulgaris L.), 60citrus species, and sage (Salvia officinalis L.) (Britto and Kronzucker, 2002). 
61 Plant preference towards $\mathrm{NO}_{3}{ }^{-}$or $\mathrm{NH}_{4}{ }^{+}$, however, may not be constant across plant 62 species but may vary with changing physiological phase and environmental conditions 63(BassiriRad et al., 1997; Britto and Kronzucker, 2013; Cui et al., 2017; Smith et al., 1990). 64In a study of $\mathrm{N}$ absorption by tomato (Solanum lycopersicum L.), for example, $50 \%$ of 65plant $\mathrm{N}$ was absorbed as $\mathrm{NH}_{4}{ }^{+}$rather than $\mathrm{NO}_{3}{ }^{-}$, even though $\mathrm{NH}_{4}{ }^{+}$only represented $10 \%$ of 66the available $\mathrm{N}$ (Glass et al., 2002). In contrast, $\mathrm{NH}_{4}{ }^{+}$fertilization of pearl millet 67(Pennisetum glaucum (L.) R. Br) under conditions that increased $\mathrm{NH}_{4}{ }^{+}$absorption over $68 \mathrm{NO}_{3}{ }^{-}$(i.e., higher $\mathrm{NH}_{4}{ }^{+}: \mathrm{NO}_{3}{ }^{-}$ratio) negatively affected its growth and development (Smith 69et al., 1990). Similarly, preference for either $\mathrm{NH}_{4}{ }^{+}$or $\mathrm{NO}_{3}{ }^{-}$has been reported in natural 70settings. In the dry, $\mathrm{NO}_{3}{ }^{-}$-rich landscape, plants tend to prefer $\mathrm{NO}_{3}{ }^{-}$while in the wet, $\mathrm{NH}_{4}{ }^{+}-$ 71rich landscape, plants tend to prefer $\mathrm{NH}_{4}^{+}$(Houlton et al., 2007; Wang et al., 2011). Since $72 \mathrm{~N}$-source preference varies within a wide range of overlapping environmental and 73physiological factors, the concept of $\mathrm{N}$ preference may only be valid for certain plant 74species, during specific developmental stages, or under definite soil conditions (Britto and 75Kronzucker, 2013). Further, the heterogeneous distribution of soil nutrients in soils can 76potentially affect $\mathrm{N}$ preference (Glass et al., 2002).

77 In a recent study, Wang and Macko (2011) argued that $\mathrm{N}$ uptake preference is 78ultimately determined by the relative abundance of $\mathrm{NH}_{4}{ }^{+}$and $\mathrm{NO}_{3}{ }^{-}$in the plants' original 79growing habitat. Indeed, several past studies indicated that $\mathrm{N}$ preference was strongly 80 affected by the dominant $\mathrm{N}$ form in soil solution, including for different crop species such 81as barley, oat (Avena sativa L.), alfalfa (Medicago sativa L.), common vetch (Vicia sativa 82L.) and pearl millet, (Cui et al., 2017; Smith et al., 1990). Therefore, the relative 
83concentration of $\mathrm{NH}_{4}{ }^{+}$and $\mathrm{NO}_{3}{ }^{-}$ions could be an important factor in determining plant $\mathrm{N}$ 84preference. Although plants can also use $\mathrm{N}$ in the form of organic $\mathrm{N}$ (e.g., amino acid), 85direct evidence that organic $\mathrm{N}$ contributes significantly to plant $\mathrm{N}$ nutrition remains scarce, 86in addition to the dependence of many crop plants on inorganic $\mathrm{N}$ sources and subsequent 87prominent role of these sources in many arable soils (Näsholm et al., 2008).

88 Based on the observation that the second generation of wild, native African grasses 89exhibited a similar $\mathrm{N}$ uptake preference as the parent plants did in the field, even when the $90 \mathrm{~N}$ sources (i.e., $\mathrm{NH}_{4}{ }^{+}: \mathrm{NO}_{3}{ }^{-}$ratios) were changed, Wang and Macko (2011) suggested a 91 'memory' effect of the $\mathrm{N}$ preference phenomenon (i.e., consistent preference). So far, there 92has been no study that tested whether this 'memory' effect also existed for agricultural 93plants. Agricultural plants can be considered as introduced or domesticated, non-native and 94non-specialized species that have experienced a significant extent of genetic modifications. 95Agricultural plants have also been grown across different environmental conditions, 96highlighting the needs for conducting this study that aimed to understand the consistency 97of plant $\mathrm{N}$ preference across generations (i.e., parent or $\mathrm{P}$ generation, the first generation or $98 \mathrm{~F} 1$ and the second generation or F2) experiencing variations in $\mathrm{N}$ speciation (expressed as 99the $\mathrm{NH}_{4}{ }^{+}$and $\mathrm{NO}_{3}{ }^{-}$ratio). The plant species that were used are corn (Zea mays L.) and 100soybean (Glycine max L.) since they represent: (i) two of the most important agricultural 101crops on earth, and (ii) two major plant functional types: non- $\mathrm{N}_{2}$-fixing $\mathrm{C}_{4}$ and $\mathrm{N}_{2}$-fixing $\mathrm{C}_{3}$ 102plants. The understanding will be crucial for increasing N-use efficiency and food 103resilience under a changing climate. For example, elevated $\mathrm{CO}_{2}$ concentration could alter 104the root uptake capacity of different $\mathrm{N}$ forms (BassiriRad et al., 1997), while the increasing 
105 frequency of drought could lead to $\mathrm{NH}_{4}{ }^{+}$dominance resulting from reduced activity of 106nitrifiers (Hartmann et al., 2013).

\section{7}

\section{Materials and methods}

\section{Plant growth}

110We obtained the publicly available and fully genome-sequenced corn and soybean seeds

111 from the United States Department of Agriculture (USDA) in Iowa, United States of

112America (USA). In our experiment, these seeds were considered the first filial (F1)

113generation of plants. Under the assumption that the parent $(\mathrm{P})$ generation of these F1 seeds

114was grown in typical farm conditions in the Midwest region of USA, we used corn and 115soybean crops grown in an agricultural field near Indianapolis, Indiana, USA as P

116generation. We acknowledge that these corn and soybean plants were not the actual P

117 generation and therefore they were only regarded as the proxy for the P generation. We,

118however, argue that this would not affect our results because both seeds have been used as 119the parent material of numerous corn and soybean varieties (Grant et al., 2008; Stojaković 120et al., 2005). Soybean is self-pollinating and all of the recessive genes in the corn seed

121have been have been eliminated, ensuring that there is no genetic deterioration of the 122offspring. The F1 seeds were grown in the greenhouse and the seeds obtained from these 123F1 plants were considered the second filial (F2) generation. These F2 seeds were 124germinated in the greenhouse and F2 plants were grown in the greenhouse until treatment. 125 The field (P) experiment was conducted when corn and soy bean plants were fully 126established in the field. Twelve corn and twelve soybean plants were selected randomly as 
127 treatment plants. These plants were tagged according to their treatment $\left({ }^{15} \mathrm{NH}_{4} \mathrm{NO}_{3}\right.$ 128treatment or $\mathrm{NH}_{4}{ }^{15} \mathrm{NO}_{3}$ treatment). In addition, four corn and four soybean plants were 129randomly selected as control. The F1 generation seeds were germinated in a greenhouse 130using commercial potting soils. On the $4^{\text {th }}$ week after planting (WAP), after washing the 131roots to remove the remaining potting soils, each of the 20 soybean and 20 corn plants was 132individually transferred into pots (one plant per pot; pot surface diameter $27.5 \mathrm{~cm}$ ) 133containing silica sand. Commercial slow-release fertilizer (Osmocote Smart-Release ${ }^{\circledR}$ ) 134containing $15 \% \mathrm{~N}\left(8.4 \%\right.$ as $\mathrm{NH}_{4}{ }^{+}-\mathrm{N}$ and $6.6 \%$ of $\left.\mathrm{NO}_{3}{ }^{-}-\mathrm{N}\right)$ was applied to each pot as the 135only source of N. Detail nutrient content of Osmocote Smart-Release ${ }^{\circledR}$ is available in the 136Supplementary Table S1. The amount of fertilizer applied (5 $\mathrm{g}$ and $10 \mathrm{~g}$ per pot for soybean 137and corn, respectively) was equivalent to $127.1 \mathrm{~kg} \mathrm{ha}^{-1} \mathrm{~N}$ for soybean and $254.2 \mathrm{~kg} \mathrm{ha}^{-1} \mathrm{~N}$ 138for corn (surface area of pot: $0.059 \times 10^{-4} \mathrm{ha}$ ). This fertilization rate is approximately 139equivalent to the recommended rate for corn growing in the field $\left(212.8-268.8 \mathrm{~kg} \mathrm{~N} \mathrm{ha}^{-1}\right)$ 140(Oberle et al., 1990). While $\mathrm{N}$ addition is generally not made to field-grown soybean crops, 14lapplication of this slow-release $\mathrm{N}$ fertilizer was needed to support plant $\mathrm{N}$ nutrition in the 142N-poor sand medium. Slow-release fertilizer was used instead of common N sources such 143as urea or anhydrous ammonia due to the lack of organic matter and reactive surfaces in 144the sand medium that could retain nutrients during the course of the experiment. 145Commercial inoculants (Burpee Booster, Warminster, PA) were used at the time of planting 146to induce root nodulation in soybean. Dicyandiamide (DCD) solution (equivalent to $4.5 \mathrm{~kg}$ 147DCD ha ${ }^{-1}$ for soybean and $9 \mathrm{~kg} \mathrm{ha}^{-1}$ for corn) was applied weekly to prevent nitrification 148during the growth of the F1 generation plants. The rate of DCD application was within the 
149range of the recommended values (1-5\%) (Azam et al., 2003), but it was applied more 150 frequently than DCD half-life (i.e., between 18 and 25 days at $\left.20^{\circ} \mathrm{C}\right)($ Di et al., 2005) to 151ensure that nitrification is effectively inhibited and that mineral $\mathrm{N}$ remains in the $\mathrm{NH}_{4}^{+}$ 152 form. Conserve ${ }^{\circledR}$ and Endeavor ${ }^{\circledR}$ insecticides were also applied periodically to prevent 153flower thrips (Frankliniella occidentalis) and aphids outbreak.

\section{$154{ }^{15} \mathbf{N}$ labelling}

155Both ${ }^{15} \mathrm{NH}_{4} \mathrm{NO}_{3}$ and $\mathrm{NH}_{4}{ }^{15} \mathrm{NO}_{3}$ were selected to provide an equal molar contribution of $156 \mathrm{NH}_{4}{ }^{+}$and $\mathrm{NO}_{3}{ }^{-}$to the plants, so that isotopic fractionation should have a minimal effect on 157the observed $\delta^{15} \mathrm{~N}$ signature patterns. The ${ }^{15} \mathrm{NH}_{4} \mathrm{NO}_{3}$ was used for the $\mathrm{NH}_{4}{ }^{+}$treatment while 158the $\mathrm{NH}_{4}{ }^{15} \mathrm{NO}_{3}$ for $\mathrm{NO}_{3}{ }^{-}$treatment. For field labelling (P generation), $19.52 \mathrm{mg}$ of ${ }^{15} \mathrm{NH}_{4} \mathrm{NO}_{3}$ 159 was combined with $8.64 \mathrm{~g}$ of $\mathrm{NH}_{4} \mathrm{NO}_{3}$ and dissolved in $480 \mathrm{ml}$ of deionized water. The 160procedure was repeated for $\mathrm{NH}_{4}{ }^{15} \mathrm{NO}_{3}$. In the field, six pairs of soybean plants were tagged 161and applied with ${ }^{15} \mathrm{~N}$ labeling during two consecutive non-rainy days (4 and 5 August 1622015). The same procedure was also applied for six pairs of corn plants. A much higher 163field enrichment (i.e., equivalent to $24,000 \%$ or 40 -times higher than the amount in 164greenhouse experiment) was designed to ensure that a traceable isotope signal could be 165detected due to a relatively higher uncertainty (more variability) in the field. Meanwhile, 166the application duration (one injection per $24 \mathrm{~h}$ interval and $48 \mathrm{~h}$ in total) was also 167designed to minimize biases caused by: (i) the potential $\mathrm{N}$ transformation processes in the 168plant medium (Wang and Macko, 2011) and (ii) rapid but oscillating plant uptake since 169studies have shown that plants could respond to nutrient addition within hours of 
170application (Jackson et al., 1990; Rabie et al., 1980; Wang and Macko, 2011; Wang et al., 1712006).

172 For greenhouse labeling (F1 and F2 generation), a much smaller amount of $173 \mathrm{NH}_{4} \mathrm{NO}_{3}(0.216 \mathrm{~g})$ was used in combination with $0.488 \mathrm{mg}{ }^{15} \mathrm{NH}_{4} \mathrm{NO}_{3}$ or $\mathrm{NH}_{4}{ }^{15} \mathrm{NO}_{3}$ 174(equivalent to $600 \%$ ), although the same amount of deionized water $(480 \mathrm{ml})$ was used for 175each ${ }^{15} \mathrm{NH}_{4}{ }^{+}$and ${ }^{15} \mathrm{NO}_{3}{ }^{-}$treatment. For both $\mathrm{F} 1$ and $\mathrm{F} 2$ generations, watering was stopped 176approximately 24 hours before labeling. In each generation, six pairs of soybean plants 177were labeled with ${ }^{15} \mathrm{NH}_{4} \mathrm{NO}_{3}$ and $\mathrm{NH}_{4}{ }^{15} \mathrm{NO}_{3}$ on two consecutive days. A total of 16 plants 178(12 labeled and 4 control) were then harvested 24 hours after the second day of labeling 179and washed to remove any potential labels that remained on the plant surface. The plants 180 were then dried in an oven $\left(60^{\circ} \mathrm{C}\right)$ until constant weight and then homogenized separately 181 for the leaves, stems, roots and pods. The same procedure was also applied for the $20 \mathrm{~F} 1$ 182corn plants. No corn plants produced seeds at the time of harvest. The remaining four 183plants (after 16 being used for treatments) were grown until maturity to produce F2 seeds. 184 For each day of application, $240 \mathrm{ml}$ of the ${ }^{15} \mathrm{NH}_{4} \mathrm{NO}_{3}$ solution was given to six 185soybean plants; each plant received $40 \mathrm{ml}$ of the ${ }^{15} \mathrm{NH}_{4}{ }^{+}$treatment. Similarly, $240 \mathrm{ml}$ of the $186 \mathrm{NH}_{4}{ }^{15} \mathrm{NO}_{3}$ was given to different six soybean plants receiving ${ }^{15} \mathrm{NO}_{3}{ }^{-}$treatment, resulting in 187a total of six pairs of soybean plants for ${ }^{15} \mathrm{NH}_{4}{ }^{+}$and ${ }^{15} \mathrm{NO}_{3}{ }^{-}$treatment. This solution was 188added in the morning around the soil surface (i.e., approximately $1 \mathrm{~cm}$ from the stem base) 189as carefully as possible to avoid touching any of the plant parts. A similar solution was also 190prepared and given to six pairs of corn plants. The same procedure was repeated on the 191following day for both soybean and corn. 
192 For F1 plants, out of the 20 soybean or 20 corn plants, 12 were treated with ${ }^{15} \mathrm{~N}$ 193enriched $\mathrm{N}$ at $10 \mathrm{WAP}$ and harvested. Four of the remaining plants were also harvested at 19410 WAP as control while the rest were left to produce seeds. These seeds were then 195harvested upon maturity and considered as F2 generation. The same planting procedure as 196the F1 generation was then repeated to test whether the N preference was carried over to 197the F2 generation. The only exception was that the F2 generation plants were planted in a 198 $\mathrm{NO}_{3}^{-}-\mathrm{N}$-rich medium to reflect the environmental changes between $\mathrm{F} 1$ and $\mathrm{F} 2$ generation 199(Fig. 1), by not applying DCD. Different measures, however, had to be applied for corn 200plants since they failed to produce seeds in the sand medium. Ten additional F1 corn plants 201 were then planted in the commercial potting soil medium and treated with the same amount 202of slow-release fertilizer as those grown in the sand under the same time frame (i.e., 4 203WAP). We assumed that the initial soil nutrient content in the soil potting mix had been 204consumed during the first four week period, which was equal to the germination period of 205the plants before being transferred to the sand. These soils were also tested for their $\mathrm{NO}_{3}^{-}$ 206and $\mathrm{NH}_{4}{ }^{+}$content (Electronic Supplemental Material Fig. S1), following the same 207procedures for the measurement of $\mathrm{NO}_{3}{ }^{-}$and $\mathrm{NH}_{4}{ }^{+}$content in the silica sand. The seeds 208produced from this soil medium was considered the F2 generation of the corn plants.

\section{Harvesting and laboratory analyses}

210All plants were then harvested 24 hours after the second day of isotopic labeling, and 211thoroughly washed to remove any labeled salts that potentially remained on the plant 212surface. We also took four unlabeled plants that were used as control. The plants were 213 chopped into pieces, then dried to constant weight in an oven $\left(60^{\circ} \mathrm{C}\right)$, and different plant 
214parts (leaves, stems, roots and pods for soybean only) were ground (homogenized) into a 215 fine powder.

216 Plant parts were analyzed separately to identify plant organs where most of $\mathrm{NO}_{3}{ }^{-}$or $217 \mathrm{NH}_{4}{ }^{+}$assimilation occurs. These organs were selected in light of the general knowledge that $218 \mathrm{NO}_{3}^{-}(\sim 33 \%)$ is reduced in corn roots, partially stored in the stalk (inside the pith cells) and 219assimilated in the leaves where the bulk of enzymes for $\mathrm{NO}_{3}{ }^{-}$assimilation are located 220(Hageman 1984). Pods were also used to indicate $\mathrm{NO}_{3}{ }^{-}$preference but only for soybean as 221 pods are considered as active sinks for newly metabolized $\mathrm{NO}_{3}^{-}-\mathrm{N}$ (Rabie et al., 1980). In 222 contrast, $\mathrm{NH}_{4}{ }^{+}$preference was only indicated by the difference between ${ }^{15} \mathrm{NO}_{3}{ }^{-}$and ${ }^{15} \mathrm{NH}_{4}{ }^{+}$ 223in the roots since soil-derived $\mathrm{NH}_{4}{ }^{+}$is assimilated exclusively in plant roots and is not 224transported to the xylem (Pearson et al., 1993). Although both F1 and F2 generations of 225soybean produced nodules, we did not separate the nodules from the roots because a 226previous study has shown that among all plant parts, the abundance of ${ }^{15} \mathrm{~N}$ was the least in 227nodules (order: root $>$ stem $>$ leaf $>$ pod $>$ nodule) (Rabie et al., 1980).

\section{Soil sampling and analysis}

229To monitor the temporal variation of $\mathrm{NO}_{3}{ }^{-}$and $\mathrm{NH}_{4}{ }^{+}$concentration in the growing medium, 230planting medium samples were taken on the 5, 6, 8, 10 WAP from five-randomly selected 231pot for plant growing in the greenhouse, including the soil used to grow seed-producing F2 232 corns. The $\mathrm{NO}_{3}{ }^{-}$and $\mathrm{NH}_{4}{ }^{+}$concentration of the field soils $(0-5 \mathrm{~cm})$, however, was only 233measured before isotope application (i.e., 4 August 2015) since there have been consistent 234findings (e.g., across 35 sites) that $\mathrm{NO}_{3}{ }^{-}$concentration in agricultural soils is generally 235higher than $\mathrm{NH}_{4}^{+}$(Crawford and Glass, 1998). All sand and soil samples were extracted 
236with water (soil:water ratio $=1: 2$ ). Extract was analyzed for $\mathrm{NH}_{4}{ }^{+}$using method microplate 237reader (Sims et al., 1995) and for $\mathrm{NO}_{3}{ }^{-}$using EPA method 353.1 on an Aquachem Konelab 23820 photometric analyzer (EST Analytical, Fairfield, OH).

\section{Isotope analysis}

240The homogenized biomass of all treatments was each weighed into tin capsules (between 1 $241 \mathrm{and} 2 \mathrm{mg})$ for isotopic analysis. The nitrogen isotope $\left(\delta^{15} \mathrm{~N}\right)$ composition was measured on 242an elemental analyzer (ECS 4100, Costech Analytical) connected under continuous helium 243 flow to an isotope ratio mass spectrometer (Delta V Plus, Thermo Scientific). By 244 convention, the $\delta^{15} \mathrm{~N}$ values were corrected and reported in units of \%o relative to 245atmospheric $\mathrm{N}_{2}$. The working reference materials are USGS $40\left(\delta^{15} \mathrm{~N}=-4.52 \%\right)$ and USGS

$24641\left(\delta^{15} \mathrm{~N}=47.57 \%\right)$. Reproducibility of these measurements was approximately $\pm 0.2 \%$.

\section{Statistical analysis}

248A student t-test was used to compare plant medium $\mathrm{NH}_{4}{ }^{+}$and $\mathrm{NO}_{3}{ }^{-}$concentration.

249Meanwhile a one-way ANOVA was used to evaluate the significance of the differences 250between ${ }^{15} \mathrm{NH}_{4}{ }^{+}$and ${ }^{15} \mathrm{NO}_{3}{ }^{-}$detected in different plant parts for all species across 251generations, followed by a Tukey post hoc test (at $P=0.05$ significance level). All analyses 252had equal sample sizes. To facilitate the visualization of the results, the degree and forms 253of $\mathrm{N}$ uptake preference at each generation were summarized for both field (P generation) 254and greenhouse settings (F1 and F2 generation), but only when the difference between $255^{15} \mathrm{NH}_{4}{ }^{+}$and ${ }^{15} \mathrm{NO}_{3}{ }^{-}$was significant. The degree and form of $\mathrm{N}$ uptake preference were 256indicated by differences between the $\delta^{15} \mathrm{~N}$ values of ${ }^{15} \mathrm{NH}_{4}{ }^{+}$and ${ }^{15} \mathrm{NO}_{3}{ }^{-}$either in root (for $257 \mathrm{NH}_{4}{ }^{+}$and $\mathrm{NO}_{3}^{-}$preference) or in leaves, stems and pods (for $\mathrm{NO}_{3}{ }^{-}$preference) (Wang and 
258Macko, 2011). If the difference $\left({ }^{15} \mathrm{NH}_{4}{ }^{+}{ }^{15} \mathrm{NO}_{3}^{-}\right)$was positive, the plant preferred $\mathrm{NH}_{4}{ }^{+}$; if 259negative, the plant preferred $\mathrm{NO}_{3}$. A value of 0 indicated that no significant preference was 260detected (Wang and Macko, 2011).

261

\section{Results}

\section{$263 \mathrm{NH}_{4}{ }^{+}$and $\mathrm{NO}_{3}{ }^{-}$in planting medium}

264Nitrate concentration was higher in the corn than in the soybean field although the $265 \mathrm{NH}_{4}^{+}: \mathrm{NO}_{3}^{-}$ratio was considered similar in both fields (Fig. 1a). During the F1 generation, 266DCD application successfully suppressed nitrification, resulting in higher $\mathrm{NH}_{4}{ }^{+}: \mathrm{NO}_{3}{ }^{-}$ratios 267compared to the field condition (Figs. 1b-c). The slow-release fertilizer also provided an 268almost constant supply of $\mathrm{N}$ during the experiment for both corn and soybean (Figs. 1b-e). 269While the planting medium during F2 generation provided a slightly higher amount of $270 \mathrm{NH}_{4}{ }^{+}$and $\mathrm{NO}_{3}{ }^{-}$compared to the field condition, the $\mathrm{NH}_{4}{ }^{+} \mathrm{NO}_{3}{ }^{-}$ratio was considered similar 271 for the field and F2 generations (Figs. 1a, 1d-e).

272 The low field soil $\mathrm{NO}_{3}{ }^{-}$and $\mathrm{NH}_{4}{ }^{+}$concentration (i.e., between 1 and $2 \mathrm{mg} \mathrm{kg}^{-1}$ soil) 273towards the end of the growing season (August 2015) was likely caused by a combination 274of plant uptake and nutrient leaching due to an excessive amount of rainfall in July 2015 275(i.e., $333 \mathrm{~mm}$ ), which was considered as the wettest July recorded in the history of this area 276according to the National Weather Service (2015). For comparison, the recent (2013-2014) 277soil $\mathrm{NO}_{3}{ }^{-}$and $\mathrm{NH}_{4}{ }^{+}$concentrations $(0-20 \mathrm{~cm})$ in Indiana range between 2 and $5 \mathrm{mg} \mathrm{kg}^{-1}$ soil 278with the $\mathrm{NH}_{4}{ }^{+}: \mathrm{NO}_{3}{ }^{-}$ratio towards the end of the growing season is $3.36: 4.45$, while the $30-$ 279year average of July rainfall is $97 \mathrm{~mm}$ (Scott, 2015). 


\section{Field (P generation) N preference}

281 When the field ( $\mathrm{P}$ generation) soil was dominated by $\mathrm{NO}_{3}^{-}$, our isotopic results showed that 282both corn and soybean preferred $\mathrm{NO}_{3}{ }^{-}$than $\mathrm{NH}_{4}^{+}$(Figs. 1 and 2). However, greater ${ }^{15} \mathrm{NO}_{3}{ }^{-}$ 283signal was observed in corn than in soybean. A significantly higher uptake of ${ }^{15} \mathrm{NO}_{3}$ was 284only found in soybean leaves while it was apparent in corn roots, stems and leaves (Fig. 2).

\section{F1 generation $\mathrm{N}$ preference}

286In contrast, when $\mathrm{NH}_{4}^{+}$was the dominant $\mathrm{N}$ species in the growth medium (i.e., $\mathrm{F} 1$ 287generation) (Figs. 1b-c), both corn and soybean exhibited a strong preference for $\mathrm{NH}_{4}{ }^{+}$, 288indicated by significantly higher ${ }^{15} \mathrm{NH}_{4}{ }^{+}$than ${ }^{15} \mathrm{NO}_{3}{ }^{-}$signal, particularly in the roots. 289Soybean preference for $\mathrm{NH}_{4}{ }^{+}$was relatively higher than with corn (Figs. 3 and 5). A higher $290{ }^{15} \mathrm{NH}_{4}$ uptake was observed in root, stem, leaf and pod of soybean plant parts while it was 291only apparent in corn roots and stems (Fig. 3).

\section{F2 generation $\mathbf{N}$ preference}

293When the planting medium was dominated by $\mathrm{NO}_{3}{ }^{-}$during the $\mathrm{F} 2$ generation (Fig. 1d-e), 294the $\mathrm{NH}_{4}{ }^{+}$preference observed during F1 generation was reversed (Fig. 4). A more 295significant ${ }^{15} \mathrm{NO}_{3}{ }^{-}$preference was found in corn with a significantly higher ${ }^{15} \mathrm{NO}_{3}{ }^{-}$content 296 found in all corn parts, but for soybean, it was only found in the pod (Figs. 4 and 5). This 297 finding was therefore similar to the field (P generation) where we found greater ${ }^{15} \mathrm{NO}_{3}{ }^{-}$ 298uptake when the soil was dominated by $\mathrm{NO}_{3}^{-}$(Figs. 1, 2, and 4). 299

\section{Discussion}

\section{Factors regulating $\mathbf{N}$ preference}


302Unlike the results of Wang and Macko (2011), the 'memory' effect (i.e., consistent 303preference) across the three generations of agricultural crops was not found in this study 304(i.e., soybean and corn), likely because these species are non-specialized species that grow 305in non-specific niche or habitat. Instead, corn and soybean were able to shift their $\mathrm{N}$ 306 preference in each generation to the more abundant form of inorganic $\mathrm{N}$ available in the 307soil. Some cereal species, such as barley and oat show a similar trend of shifting preference 308 following changes in the soil $\mathrm{NH}_{4}{ }^{+}: \mathrm{NO}_{3}{ }^{-}$ratio (Cui et al., 2017). Shoot $\mathrm{NO}_{3}{ }^{-}$assimilation 309also generally increases as external $\mathrm{NO}_{3}{ }^{-}$concentration increases for annual legumes and 310non-legume species (Andrews, 1986). In forest ecosystems, tree species, Hinoki cypress 311 (Chamaecyparis obtusa Endlicher), has flexibility in absorbing either $\mathrm{NH}_{4}{ }^{+}$or $\mathrm{NO}_{3}{ }^{-}$, 312depending on availability (Takebayashi et al., 2010). Similarly, functionally diverse plant 313groups show inherent flexibility to absorb different $\mathrm{N}$ forms by consistently preferring the 314more abundant form of inorganic $\mathrm{N}$ in the soil (Houlton et al., 2007). Our results provide 315further evidence that plant preference for a given $\mathrm{N}$ form $\left(\mathrm{NH}_{4}{ }^{+}\right.$or $\left.\mathrm{NO}_{3}{ }^{-}\right)$may shift and the 316shift is mainly determined by the abundance and availability of each form, as has been 317indicated by several other studies (Cui et al., 2017; Houlton et al., 2007; Kronzucker et al., 3181997; Smith et al., 1990; Wallander et al., 1997; Wang and Macko, 2011). We suggest, 319however, that there is a threshold for $\mathrm{NH}_{4}{ }^{+}: \mathrm{NO}_{3}{ }^{-}$ratio before such preference changes and 320the threshold is related to, for example, the precipitation gradient in natural system (Wang 321 and Macko, 2011). Higher $\mathrm{NH}_{4}{ }^{+}: \mathrm{NO}_{3}{ }^{-}$ratio in the wetter end of the gradient due to high 322 decomposition rate (more ammonium availability) but high $\mathrm{NO}_{3}^{-}$leaching leads to plant 
323preference towards $\mathrm{NH}_{4}^{+}$(Wang and Macko, 2011). There is a switch, however, to $\mathrm{NO}_{3}{ }^{-}$

324preference as $\mathrm{NH}_{4}{ }^{+}: \mathrm{NO}_{3}{ }^{-}$ratio becomes lower at the drier sites (Houlton et al., 2007).

325 While some plants can switch their nutrient uptake preference depending on

326nutrient availability (i.e., $\mathrm{NH}_{4}{ }^{+}: \mathrm{NO}_{3}{ }^{-}$ratio), strong preference towards a specific $\mathrm{N}$ form has

327 been observed in some plant species. Since $\mathrm{NH}_{4}{ }^{+}$uptake and its assimilation in general are 328considered to be energy efficient, one can assume that $\mathrm{NH}_{4}{ }^{+}$will be the preferred $\mathrm{N}$ form, 329at least under equimolar $\mathrm{NH}_{4}^{+}: \mathrm{NO}_{3}{ }^{-}$scenarios. However, past studies have shown that, in 330some species, $\mathrm{NH}_{4}{ }^{+}$was not always the preferred $\mathrm{N}$ form to support plant growth (Errebhi 331et al., 1990; Smith et al., 1990). In a pearl millet study, Smith et al. (1990) shows that 332 when present in an equimolar ratio, $\mathrm{NO}_{3}{ }^{-}$is preferred over $\mathrm{NH}_{4}{ }^{+}$. However, when the $333 \mathrm{NH}_{4}{ }^{+}: \mathrm{NO}_{3}{ }^{-}$ratio is increased to $3: 1$, the plant was forced to absorb more $\mathrm{NH}_{4}{ }^{+}$, but overall 334N uptake was reduced resulting in lower yield (Smith et al., 1990). Similarly, Errebhi et al. 335(1990) find that corn experiences a reduction in dry weight and cation absorption $\left(\mathrm{K}^{+}, \mathrm{Ca}^{+}\right.$, $336 \mathrm{Mg}^{2+}$ ) when provided with an equimolar amount of $\mathrm{NH}_{4}{ }^{+}$and $\mathrm{NO}_{3}{ }^{-}$. The same finding, 337however, is not observed at low (i.e., $<1) \mathrm{NH}_{4}{ }^{+}: \mathrm{NO}_{3}{ }^{-}$ratios. In contrast, high $\mathrm{NO}_{3}{ }^{-}$ 338 concentration is found to have an inhibitory effect on nodule growth and activity in several 339legumes species, including soybean, white clover (Trifolium repens L.), and pea (Pisum 340sativum L.), by reducing nitrogenase enzyme, which is not observed in soil with high $\mathrm{NH}_{4}{ }^{+}$ 341concentration (Bollman et al., 2006; Streeter, 1985; Svenning et al., 1996). Bean 342(Phaseolus vulgaris L.) dry weight is also not significantly different between different $343 \mathrm{NH}_{4}{ }^{+}: \mathrm{NO}_{3}{ }^{-}$ratios which varied from 0:11, 1:10, 2:9 and 1:1 (Errebhi and Wilcox, 1990). 
344 Apart from species, the shift of plant $\mathrm{N}$ preference is also affected by plant 345physiological maturity, either under a changing (Cui et al., 2017) or constant (Smith et al., 3461990) $\mathrm{NH}_{4}^{+}: \mathrm{NO}_{3}^{-}$ratio. Smith et al. (1990) and Cui et al. (2017) both find that during their 347early growth phase, plants prefer $\mathrm{NH}_{4}{ }^{+}$over $\mathrm{NO}_{3}{ }^{-}$, but such preference is reversed during 348late growth phase, which could be related to: (i) $\mathrm{NH}_{4}{ }^{+}$detoxification and/or (ii) the 349reduction of carbohydrate available associated with the beginning of reproductive phase. 350This pattern of juvenile $\mathrm{NH}_{4}{ }^{+}$preference and mature plant preference for $\mathrm{NO}_{3}{ }^{-}$is found to 351be quite consistent across different cereal species, including rice (Oryza sativa L.), pearl 352millet, barley and oat (Cui et al., 2017; Errebhi and Wilcox, 1990; Smith et al., 1990). 353Therefore, the same tendency for $\mathrm{NO}_{3}{ }^{-}$preference by mature plants would explain the 354strong $\mathrm{NO}_{3}{ }^{-}$preference in corn plants near harvest time (10 WAP; Figs. 2, 4). 355 Plant $\mathrm{N}$ preference can also be linked to the need of growing plants to maintain 356their anion or cation balance (von Wirén et al., 1997), and is therefore highly time 357dependent (Rabie et al., 1980). An increase of $\mathrm{NO}_{3}{ }^{-}$uptake rate in corn was observed that 358experiencing $\mathrm{N}$ deficiency only within a few hours after $\mathrm{N}$ addition (Rabie et al., 1980; von 359Wirén et al., 1997), although the rate could decline after a prolonged exposure to $\mathrm{NO}_{3}$. 360This result suggests that there is a potential continuous feedback from the plant since plant $361 \mathrm{NO}_{3}{ }^{-}$uptake will again increase if $\mathrm{NO}_{3}{ }^{-}$availability in the soil declines (von Wirén et al., 3621997). Similar increase of $\mathrm{NO}_{3}^{-}$uptake, however, is not observed with $\mathrm{NH}_{4}{ }^{+}$(von Wirén et 363al., 1997). The latter finding was consistent with our F1 generation observation (Fig. 3) 364where there was a relatively low $\mathrm{NH}_{4}{ }^{+}$uptake for corn despite it was grown under $\mathrm{N}$ 365limited conditions (as indicated by its failure to produce seed). Based on potential risk of 
$366 \mathrm{NH}_{4}{ }^{+}$toxicity, it is suggested that certain plants (i.e., corn in our study) will avoid $\mathrm{NH}_{4}{ }^{+}$ 367accumulation, likely because the rate of $\mathrm{NH}_{4}{ }^{+}$assimilation is generally lower than its 368uptake (von Wirén et al., 1997).

\section{Physiological mechanisms of $\mathbf{N}$ preference}

370Plant species preference towards $\mathrm{NO}_{3}{ }^{-}$or $\mathrm{NH}_{4}{ }^{+}$can vary from one species to another. While 371 most cereal species seemed to prefer $\mathrm{NO}_{3}{ }^{-}$over $\mathrm{NH}_{4}{ }^{+}$, except for those grown in acid soils 372such as rice which showed preference towards $\mathrm{NH}_{4}{ }^{+}$(Zhao et al., 2013), legumes have 373shown greater flexibility in regards to both forms of $\mathrm{N}$, although there was a tendency 374towards $\mathrm{NH}_{4}{ }^{+}$preference (Figs. 2-5). In our experiment, greater $\mathrm{NH}_{4}{ }^{+}$incorporation (almost 375double) than $\mathrm{NO}_{3}^{-}$was shown within 48 hours after treatment into soybean roots (Fig. 3), 376 consistent with a study by Ohyama et al. (1989). In soybean, $\mathrm{NH}_{4}{ }^{+}$is actively incorporated 377 into amides, much of which remains in the roots (Weissman, 1972). Stronger preference to $378 \mathrm{NH}_{4}{ }^{+}$in soybean may also be caused by the long-term effect of $\mathrm{N}$ assimilatory products 379(i.e., amino acids) since $\mathrm{NO}_{3}{ }^{-}$uptake can be inhibited by phloem-translocated amino acids 380such as alanine, glutamic acid, aspartic acid, arginine and asparagine (Muller et al., 1992).

381 Although the presence of mycorrhiza was not checked in our study, in its natural 382habitat, close association with mycorrhiza likely accounts for the preferential uptake of $383 \mathrm{NH}_{4}{ }^{+}$by soybean. Mycorrhiza has been known to absorb $\mathrm{NH}_{4}{ }^{+}$and transfer a substantial 384amount of $\mathrm{N}$ to the host plant (Kobae et al., 2010). Mycorrhiza has also been shown to 385enhance $\mathrm{NH}_{4}{ }^{+}$but not $\mathrm{NO}_{3}{ }^{-}$absorption rates (Kronzucker et al., 1997), likely because there 386are two $\mathrm{NH}_{4}{ }^{+}$uptake sites for the mycorrhizal plants: the root-soil interface and the 387hyphae-soil interface (Marschner et al., 1994). The recent discovery of membrane protein 
388(nod26) confirmed the increase in permeability of root membrane to $\mathrm{NH}_{4}{ }^{+}$, allowing 389transport of fixed $\mathrm{N}_{2}$ in the form of $\mathrm{NH}_{3}$ from the symbiosome (Hwang et al., 2010). Of the $39016 \mathrm{NH}_{4}{ }^{+}$transporter genes found in the soybean genome, five were induced by mycorrhiza 391(Kobae et al., 2010).

392 On the other hand, the relatively fewer $\mathrm{NH}_{4}{ }^{+}$transporters found in the corn genome 393could cause the lower affinity for $\mathrm{NH}_{4}{ }^{+}$observed in corn (Figs. 3 and 5). So far only two $394 \mathrm{NH}_{4}{ }^{+}$transporter genes have been isolated from the corn genome: $\mathrm{ZmAMT1;1a}$ and 395ZmAMT1;3 (Gu et al., 2013). These transporters were based on High Affinity Transport 396Systems in corn roots which allowed $\mathrm{NH}_{4}{ }^{+}$ions to be absorbed according to the 397electrochemical gradient (Gu et al., 2013). As $\mathrm{NH}_{4}{ }^{+}$concentration in plant cells increased, 398a reduction in $\mathrm{NO}_{3}{ }^{-}$uptake capacity was observed (George, 2014, MacKown et al., 1982) 399 since $\mathrm{NH}_{4}{ }^{+}$would cause membrane depolarization and block the anion transport system 400(Ullrich, 1992). This trend, however, could be reversed by growing the plant in a $\mathrm{NO}_{3}^{-}$-rich 401medium (George, 2014). The same observation was also noted in pearl millet (Smith et al., 4021990), likely due to the inhibition of $\mathrm{NO}_{3}^{-}$reductase activity by $\mathrm{NH}_{4}^{+}$.

403 Overall, we found that plant preference is dependent upon $\mathrm{NH}_{4}^{+}: \mathrm{NO}_{3}^{-}$ratio, 404although plants have a certain degree of preference in their ability to absorb either $\mathrm{NH}_{4}{ }^{+}$or $405 \mathrm{NO}_{3}{ }^{-}$. In natural ecosystems, pine trees, that have generally been considered as $\mathrm{NH}_{4}{ }^{+}$ 406absorber, can show high reliance on $\mathrm{NO}_{3}{ }^{-}$as $\mathrm{NO}_{3}{ }^{-}$becomes more available in the soil 407(Takebayashi et al., 2010). In our experiment, stronger preference for $\mathrm{NO}_{3}{ }^{-}$was observed 408in corn (Fig. 5), consistent with the observation that most agricultural crops appeared to 409prefer $\mathrm{NO}_{3}{ }^{-}$over $\mathrm{NH}_{4}{ }^{+}$(Britto and Kronzucker, 2013). Some exceptions were observed in 
410plants that have the ability to assimilate $\mathrm{NH}_{4}^{+}$(i.e., legumes) (Fig. 5) or adapted to live in 411waterlogged and acid condition (e.g., rice) (Zhao et al., 2013). Since high $\mathrm{NH}_{4}^{+}$

412concentration is toxic to plants, the amount of $\mathrm{NH}_{4}{ }^{+}$is kept to a minimum in plant tissue by 413two mechanisms: (i) assimilation in the roots and/or (ii) enhanced efflux of $\mathrm{NH}_{4}^{+}$to the 414external medium (Britto and Kronzucker, 2013). Both processes have been suggested to 415eliminate any energetic advantages conferred by the uptake of $\mathrm{NH}_{4}{ }^{+}$(Britto and 416Kronzucker, 2013). Ammonia assimilation in the roots reduces the amount of carbon 417available for plant growth and maintenance, and at the same time, increasing efflux of $418 \mathrm{NH}_{4}{ }^{+}$to external medium is an 'energetically costly futile cycle' (Britto and Kronzucker, 4192013). Indeed, a reduction in the amount of soluble sugar content in corn shoot tissue was 420significantly reduced when plant was treated with $\mathrm{NH}_{4}{ }^{+}$due to high requirement of carbon 421skeletons for $\mathrm{NH}_{4}{ }^{+}$incorporation into amino acids (Magalhães et al., 1993).

422 In our study, it was shown that irrespective of generation, both corn and soybean 423consistently exhibited a preference for the $\mathrm{N}$ species that dominate the mineral $\mathrm{N}$ pool in 424the growing medium and stronger responses were generally observed in roots compared to 425other plant tissues. While plants will try to make use of the most available form of $\mathrm{N}$ in its 426growing medium, plant species, physiological characteristics (i.e., maturity, association 427with mycorrhiza) and plant nutrient status also determine the $\mathrm{N}$ uptake preference. In our 428study, the magnitude of the response of soybean (legume) towards $\mathrm{NH}_{4}{ }^{+}$was generally 429stronger than that of corn (non-legume). Although our study showed that soybean and corn 430did not have consistent plant preference (or 'memory' effect), there was a possibility that 431either plasticity or consistency was genetically inherited. Consistency across plant 
432generations (as observed by Wang and Macko (2011), however, are more likely observed 433in habitat specialists, such conifers that live in acid soils. For agricultural crops, plasticity, 434as shown in our study, is beneficial from the evolutionary point of view because plants can 435effectively acquire available $\mathrm{N}$ to alleviate their $\mathrm{N}$ demand according to availability of the 436dominant $\mathrm{N}$ forms (Cui et al., 2017) and maintain their productivity. From an agronomical 437perspective, our understanding on plant nutrient preference and a plant's ability to switch 438between different $\mathrm{N}$ forms is also important to adapt to other environmental changes, 439particularly changes in precipitation. Reduction or increase in the amount of rainfall may 440potentially increase $\mathrm{NH}_{4}^{+}: \mathrm{NO}_{3}{ }^{-}$ratio by slowing down the rate of nitrification or reducing 441 the concentration of $\mathrm{NO}_{3}{ }^{-}$since $\mathrm{NO}_{3}{ }^{-}$is a much more leachable $\mathrm{N}$ species than $\mathrm{NH}_{4}{ }^{+}$.

\section{2}

\section{Acknowledgements}

444We acknowledge the North Central Regional Plant Introduction Station (NCRPIS) USDA 445at Iowa State University for donating of the corn and soybean seeds planted during the 446experiments. This work was supported by Schlumberger Foundation and United States 447Department of Agriculture (USDA) grant [2014-51130-22492]. We thank Dr. Greg 448Druschel for assistance in validating the soil test and Krista Phelps for assistance during 449the field sampling. We also thank Dr, Wei Wei, Quanlai Zhou, Farai Kaseke, Lara 450Martinez, and Dawn Bauman for assistance during greenhouse works.

\section{1}

\section{References}

453Andrews M (1986) The partitioning of nitrate assimilation between root and shoot of 454higher plants. Plant Cel Environment 9:511-19. 
455Azam F, Farooq S (2003) Nitrification inhibition in soil and ecosystem functioning-an 456overview. Pak J Biol Sci 6:528-35.

457BassiriRad H, Griffin KL, Reynolds JF, et al. (1997) Changes in root $\mathrm{NH}_{4}{ }^{+}$and $\mathrm{NO}_{3}{ }^{-}$ 458absorption rates of loblolly and ponderosa pine in response to $\mathrm{co}_{2}$ enrichment. Plant Soil 459190:1-9.

460Bollman MI, Vessey JK (2006) Differential effects of nitrate and ammonium supply on 461nodule initiation, development, and distribution on roots of pea (Pisum sativum). Can J 462Bot 84:893-903.

463Britto DT, Kronzucker HJ (2002) $\mathrm{NH}_{4}{ }^{+}$toxicity in higher plants: A critical review. J Plant 464Physiol 159:567-84.

465Britto DT, Kronzucker HJ (2013) Ecological significance and complexity of N-source 466preference in plants. Ann Bot 112:957-63.

467Craine J, Brookshire ENJ, Cramer M, et al. (2015) Ecological Interpretations of nitrogen 468isotope ratios of terrestrial plants and soils. Plant Soil 396: 1-26.

469Crawford NM, Glass AD (1998) Molecular and physiological aspects of nitrate uptake in 470plants. TRENDS Plant Sci 3:389-95.

471Criddle RS, Ward MR, Huffaker RC (1988) Nitrogen uptake by wheat seedlings, 472 interactive effects of four nitrogen sources: $\mathrm{NO}_{3}{ }^{-}, \mathrm{NO}_{2}{ }^{-}, \mathrm{NH}_{4}{ }^{+}$, and urea. Plant Physiol 47386:166-75.

474Cui J, Yu C, Qiao N, et al. (2017) Plant preference for $\mathrm{NH}_{4}{ }^{+}$versus $\mathrm{NO}_{3}{ }^{-}$at different 475growth stages in an alpine agroecosystem. Field Crop Res 201:192-99. 
476Di H, Cameron K (2005) Effects of temperature and application rate of a nitrification 477inhibitor, dicyandiamide (DCD), on nitrification rate and microbial biomass in a grazed 478pasture soil. Soil Res 42:927-32.

479Errebhi M, Wilcox G (1990) Plant species response to ammonium-nitrate concentration 480ratios. J Plant Nutr 13:1017-1029.

481George J (2014) Nitrate and ammonium interactions in maize. PhD thesis, University of 482Adelaide, Australia.

483Glass A, de Britto T, Kaiser B, et al. (2002) The regulation of nitrate and ammonium 484transport systems in plants. $J$ Exp Bot 53:855-64.

485Grant D, Nelson R, Graham M, Shoemaker R (2008) Bioinformatic resources for soybean 486genetic and genomic research. In Stacey G (ed) Genetics and genomics of soybean. New 487York, USA: Springer-Verlag, 141-159.

488Gu R, Duan F, An X, et al. (2013) Characterization of amt-mediated high-affinity 489ammonium uptake in roots of maize (Zea mays L.). Plant Cell Physiol 54:1515-24. 490Hageman R (1984) Ammonium versus nitrate nutrition of higher plants. Nitrogen in Crop 491Production. Wisconsin, USA: American Society of Agronomy, Crop Science Society of 492America, Soil Science Society of America, 67-85.

493Hartmann AA, Barnard RL, Marhan S, et al. (2013) Effects of drought and N-fertilization 494on n cycling in two grassland soils. Oecologia 171:705-17.

495Houlton BZ, Sigman DM, Schuur EA, et al. (2007) A climate-driven switch in plant 496nitrogen acquisition within tropical forest communities. Proc Nat Ac Sci 104:8902-06. 
497Hwang JH, Ellingson SR, Roberts DM (2010) Ammonia permeability of the soybean 498nodulin 26 channel. FEBS letters 584:4339-43.

499Jackson R, Manwaring J, Caldwell M (1990) Rapid physiological adjustment of roots to 500localized soil enrichment. Nature 344:58-60.

501Kobae Y, Tamura Y, Takai S, et al. (2010) Localized expression of arbuscular mycorrhiza502inducible ammonium transporters in soybean. Plant Cell Physiol 51:1411-15.

503Kronzucker HJ, Siddiqi MY, Glass AD (1997) Conifer root discrimination against soil 504nitrate and the ecology of forest succession. Nature 385:59-61.

505MacKown CT, Jackson WA, Volk RJ (1982) Restricted nitrate influx and reduction in corn 506seedlings exposed to ammonium. Plant Physiol 69:353-59.

507Magalhães JR, Machado AT, Fernandes M, et al. (1993) Nitrogen assimilation efficiency 508in maize genotypes under ammonia stress. Rev Bras Fisiol Veg 5:163-66.

509Marschner H, Dell B (1994) Nutrient uptake in mycorrhizal symbiosis. Plant Soil 159:89510102.

511Muller B, Touraine $\mathrm{B}$ (1992) Inhibition of $\mathrm{NO}_{3}{ }^{-}$uptake by various phloem-translocated 512amino acids in soybean seedlings. J Exp Bot 43:617-23.

513Näsholm T, Kielland K, Ganeteg U (2008) Uptake of organic nitrogen by plants. New 514Phytol 182:31-48.

515Oberle S, Keeney D (1990) Factors influencing corn fertilizer N requirements in the 516northern US corn belt. J Prod Agric 3:527-34.

517Ohyama T, Saito K, Kato N (1989) Assimilation and transport of nitrate, nitrite, and 518ammonia absorbed by nodulated soybean plants. Soil Sci Plant Nutr 35:9-20. 
519Pearson J, Stewart GR (1993) The deposition of atmospheric ammonia and its effects on 520plants. New Phytol 125:283-305.

521Rabie RK, Arima Y, Kumazawa K (1980) Uptake and distribution of combined nitrogen 522and its incorporation into seeds of nodulated soybean plants as revealed by ${ }^{15} \mathrm{~N}$ studies. 523Soil Sci Plant Nutr 26:427-36.

524Schortemeyer M, Feil B (1996) Root morphology of maize under homogeneous or 525spatially separated supply of ammonium and nitrate at three concentration ratios. Journal 526of plant nutrition 19:1089-1097.

527Scott JR (2015) Corn nitrogen rates: Residual effects on soil fertility and soybean. Master 528thesis, Purdue University, USA.

529Sims G, Ellsworth T, Mulvaney R (1995) Microscale determination of inorganic nitrogen 530in water and soil extracts. Comm Soil Sci Plant Anal 26:303-16.

531Smith R, Mills H, Hoveland C, et al. (1990) Influence of ammonium:nitrate ratios on the 532growth and nitrogen uptake of pearl millet. J Plant Nutr 13:541-53.

533Stojaković M, Bekavac G, Vasić N (2005) B73 and related inbred lines in maize breeding 534Genetika 37:245-52.

535Streeter JG (1985) Nitrate inhibition of legume nodule growth and activity ii. Short term 536studies with high nitrate supply. Plant Physiol 77:325-28.

537Svenning MM, Junttila O, Macduff JH (1996) Differential rates of inhibition of $\mathrm{N}_{2}$ 538fixation by sustained low concentrations of $\mathrm{NH}_{4}{ }^{+}$and $\mathrm{NO}_{3}$ in northern ecotypes of white 539clover (trifolium repens 1.). J Exp Bot 47:729-38. 
540Takebayashi Y, Koba K, Sasaki Y, et al. (2010) The natural abundance of ${ }^{15} \mathrm{~N}$ in plant and 541soil-available $\mathrm{n}$ indicates a shift of main plant $\mathrm{N}$ resources to $\mathrm{NO}_{3}{ }^{-}$from $\mathrm{NH}_{4}{ }^{+}$along the $\mathrm{N}$ 542leaching gradient. Rapid Commun Mass Spectrom 24:1001-08.

543Ullrich W (1992) Transport of nitrate and ammonium through plant membranes. In Mengel 544K, Pilbeam D (eds) Nitrogen metabolism of plants. Oxford, UK: Clarendon Press, 121-37. 545von Wirén N, Gazzarrini S, Frommer WB (1997) Regulation of mineral nitrogen uptake in 546plants. Plant Soil 196:191-99.

547Wallander H, Arnebrant K, Östrand F, et al. (1997) Uptake of ${ }^{15} \mathrm{~N}$-labelled alanine, 548ammonium and nitrate in Pinus sylvestris L. Ectomycorrhiza growing in forest soil treated 549with nitrogen, sulphur or lime. Plant Soil 195:329-38.

550Wang L, D’Odorico P, Ries L, et al. (2010) Combined effects of soil moisture and nitrogen 551availability variations on grass productivity in african savannas. Plant Soil 328:95-108. 552Wang L, Macko SA (2011) Constrained preferences in nitrogen uptake across plant 553species and environments. Plant Cell Environ 34:525-34.

554Wang L, Mou PP, Jones RH (2006) Nutrient foraging via physiological and morphological 555plasticity in three plant species. Can J Forest Res 36:164-73.

556Weissman GS (1972) Influence of ammonium and nitrate nutrition on enzymatic activity in 557soybean and sunflower. Plant Physiol 49:138-41.

558Zhao XQ, Guo SW, Shinmachi F, et al. (2013) Aluminium tolerance in rice is antagonistic 559with nitrate preference and synergistic with ammonium preference. Ann Bot 111:69-77. 560

561

562 


\section{Figure captions}
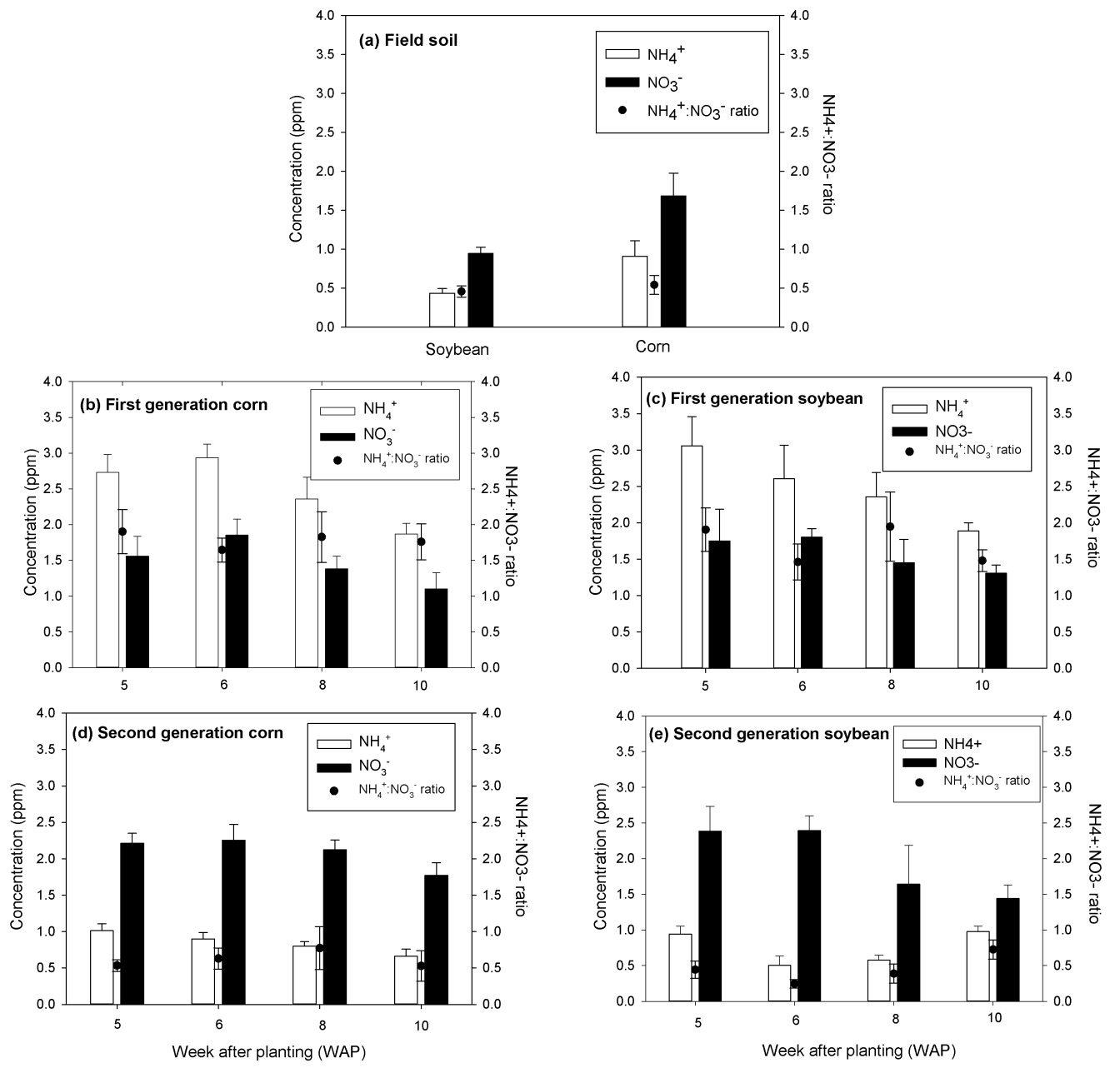

564

565Fig. 1. Ammonium and nitrate concentration (mean \pm SD) in plant growing medium across 566several generations of soybean and corn.

567 


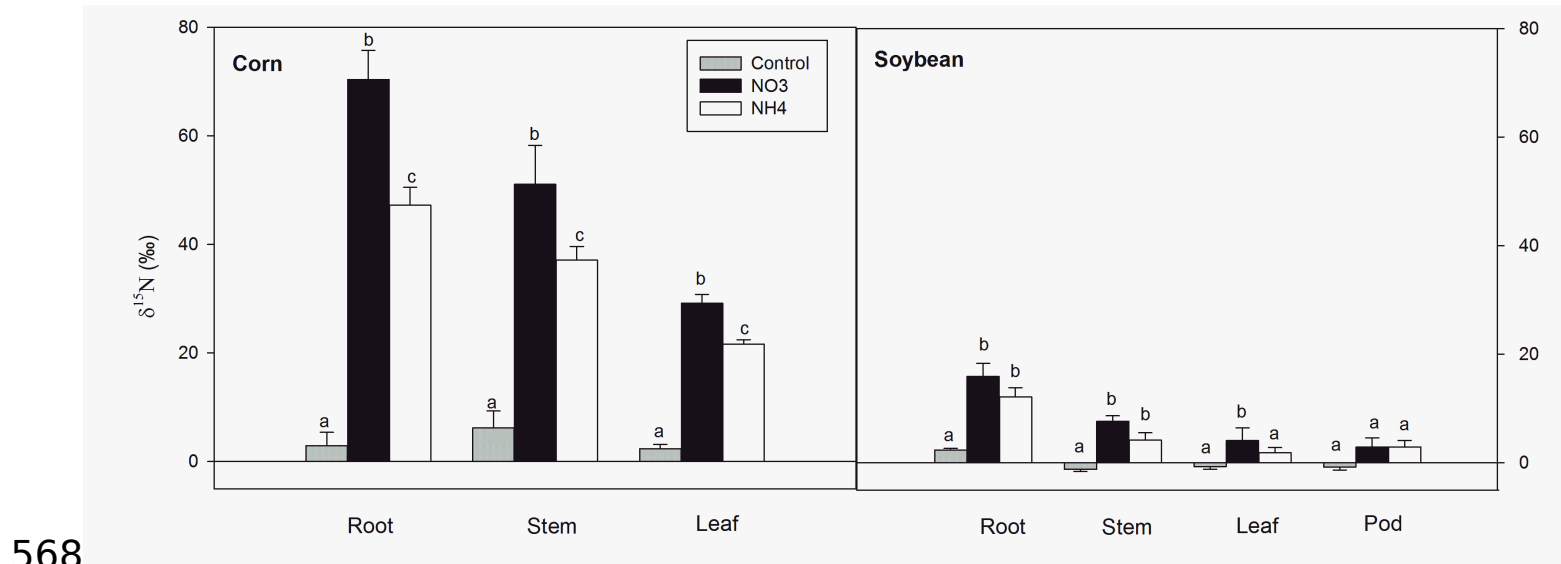

568

569Fig. 2. Differences of $\mathrm{N}$ uptake in different plant parts for corn and soybean in the field (P 570 generation; mean $\pm \mathrm{SD}$ ). Letters 'a', 'b' and 'c' indicate significant differences at $P<0.05$.

571

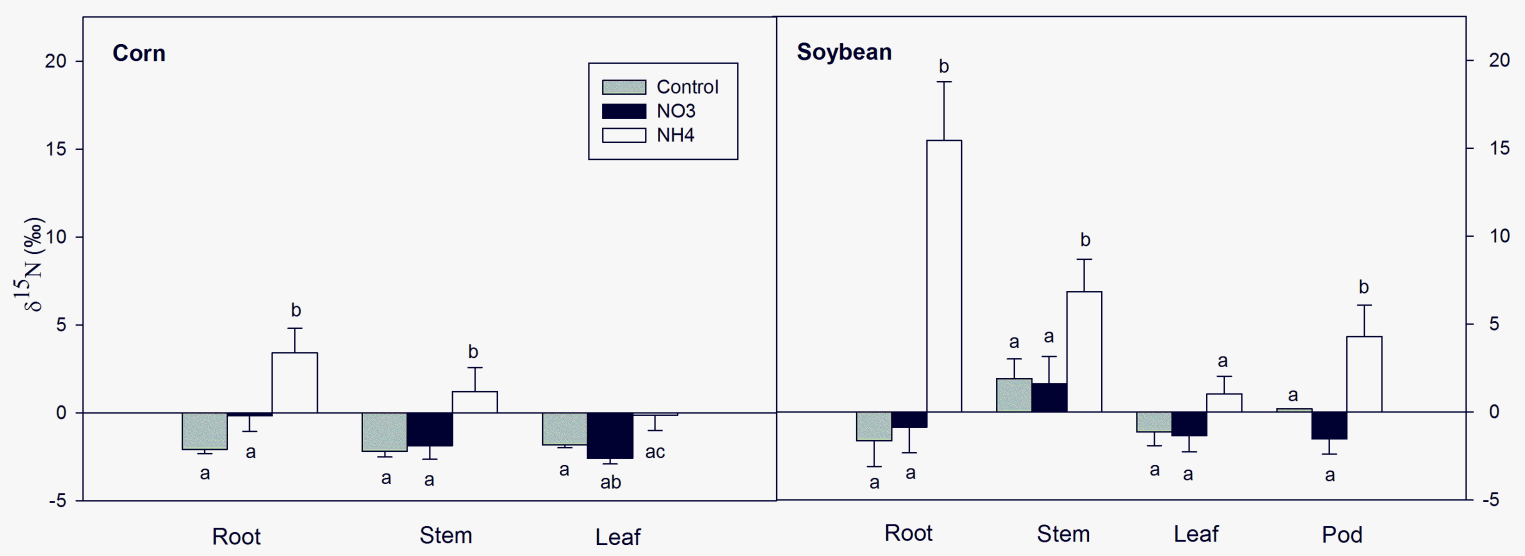

572

573Fig. 3. Differences of $\mathrm{N}$ uptake in different plant parts for corn and soybean during F1

574generation (mean $\pm \mathrm{SD}$ ). Letters ' $a$ ', 'b' and 'c' indicate significant differences at $P<0.05$.

575 


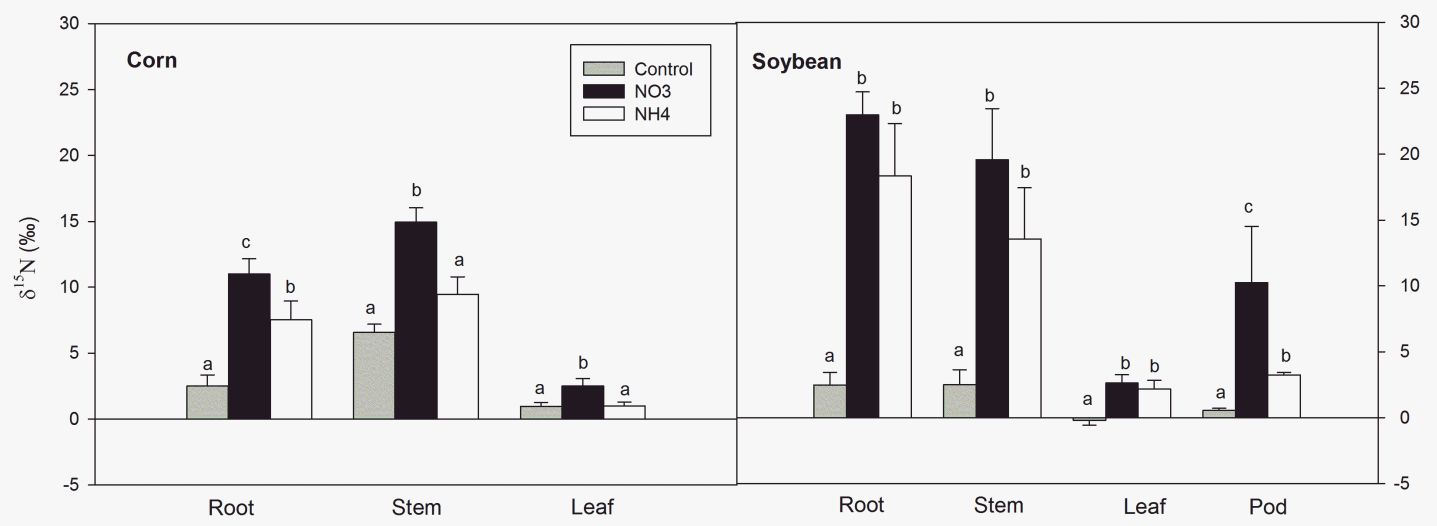

576

577Fig. 4. Differences of $\mathrm{N}$ uptake in different plant parts for corn and soybean during F2 578generation (mean $\pm \mathrm{SD}$ ). Letters ' $a$ ', 'b' and 'c' indicate significant differences at $P<0.05$. 579

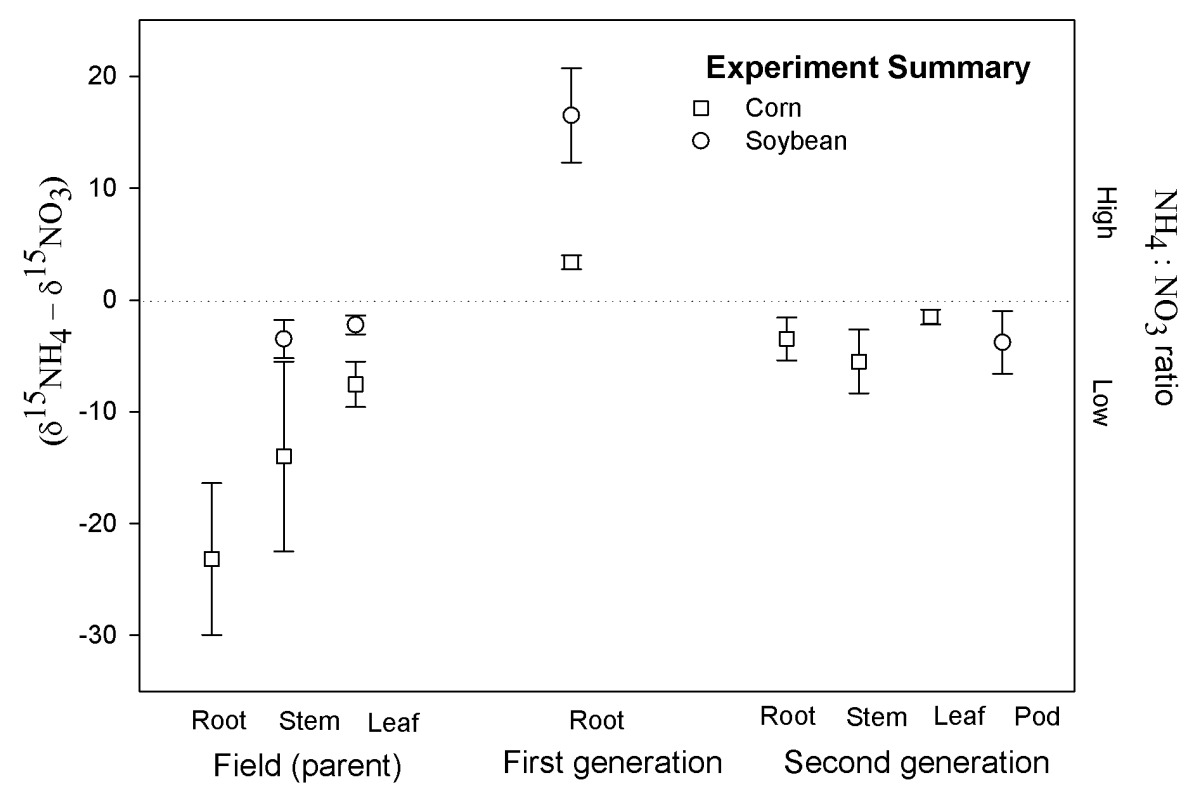

580

581Fig. 5. Summary of $N$ preference for soybean and corn (mean \pm SD) under a changing $582 \mathrm{NH}_{4}^{+}: \mathrm{NO}_{3}{ }^{-}$ratio. 